\title{
Idiopathic CD4 Lymphocytopenia (HIV-Negative AIDS): Case Report and Literature Review
}

\author{
Idiyopatik CD4 Lenfositopeni (HIV-Negatif AIDS): Olgu Sunumu ve Literatür Derlemesi
}

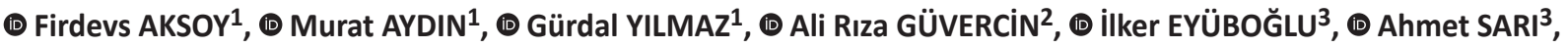 \\ ๑ G Gülçin BAYRAMOĞLU4 ${ }^{4}$, ๑ iftihar KÖKSAL ${ }^{1}$ \\ ${ }^{1}$ Karadeniz Technical University Faculty of Medicine, Department of Infectious Diseases and Clinical Microbiology, Trabzon, Turkey \\ ${ }^{2}$ Karadeniz Technical University Faculty of Medicine, Department of Neurosurgery, Trabzon, Turkey \\ ${ }^{3}$ Karadeniz Technical University Faculty of Medicine, Department of Radiology, Trabzon, Turkey \\ ${ }^{4}$ Karadeniz Technical University Faculty of Medicine, Department of Medical Microbiology, Trabzon, Turkey
}

\section{Abstract}

Idiopathic CD4 lymphocytopenia (ICL), also known as non-HIV AIDS, is a rare disease characterized by opportunistic infections, malignancies, and autoimmune diseases. Idiopathic CD4 lymphocytopenia is defined as CD4+ T-lymphocyte level below 300/mm in at least two measurements or less than $20 \%$ of total lymphocytes, which cannot be explained by any other condition, including HIV infection. Nocardia spp. are opportunistic microorganisms that is a frequent cause of infection in immunocompromised individuals. In this paper, we report a 50-year-old patient with ICL and intracranial brain abscess due to Nocardia farcinica and review th literature for related articles published between April 2012 and December 2018. These data suggest that there may be an underlying immunosuppression in adult patients who have infections that are recurrent, refractory, and caused by opportunistic pathogens.

Keywords: T-lymphocytopenia, idiopathic CD4-positive, rare diseases, Nocardia, nocardiosis

\section{Öz}

Non-HIV AIDS olarak da bilinen idiyopatik CD4 lenfositopeni (ICL) nadir görülen bir hastalık olup fırsatçı enfeksiyonlar, maligniteler ve otoimmün hastalıklarla seyredebilmektedir. İdiyopatik CD4 lenfositopenisi, CD4+ T-lenfositlerin en az iki ölçümde 300/mm'den az ya da lenfositlere oranının \%20'den az olması ve bunun HIV enfeksiyonu da dahil başka alternatif durumla açıklanamaması şeklinde tanımlanır. Nocardia türleri fırsatçı mikroorganizmalar olup sıklıkla immünokompromize bireylerde enfeksiyonlara yol açarlar. Bu yazıda 50 yaşında, N. farcinica'ya bağlı intrakraniyal beyin apsesi ile seyreden bir ICL olgusu sunulmuştur. Ayrıca Nisan 2012-Aralık 2018 tarihleri arasındaki ilgili literatür taraması yapılmıştır. Bu veriler erişkin olgularda tekrarlayan, tedavi edilemeyen ve fırsatçı patojenlerle gelişen enfeksiyonlarda altta yatan bir immünosüpresyon olabileceğine dikkat çekmek amaçlanmıştır.

Anahtar Kelimeler: T-lenfositopeni, idiyopatik CD4-pozitif, nadir hastalıklar, Nocardia, nokardiyoz

\section{Introduction}

Idiopathic CD4 lymphocytopenia (ICL) is a rare condition ${ }^{[1]}$ that was first described in 1992 by the US Centers for Disease Control and Prevention. ICL is defined as CD4+ T-lymphocyte count below
$300 / \mathrm{mm}^{3}$ or comprising less than $20 \%$ of the total lymphocytes in at least two measurements. In addition, it is characteristically unassociated with human T-lymphotropic virus 1 (HTLV-1), HTLV-2, or any primary/secondary immunodeficiency condition, including HIV infection ${ }^{[2,3]}$. Idiopathic CD4 Iymphocytopenia has

Cite this article as: Aksoy F, Aydın M, Yılmaz G, Güvercin AR, Eyüboğlu İ, Sarı A, Bayramoğlu G, Köksal İ. Idiopathic CD4 Lymphocytopenia (HIV-negative AIDS): Case Report and Literature Review. Mediterr J Infect Microb Antimicrob.2019;8:24.

Address for Correspondence/Yazışma Adresi: Firdevs Aksoy MD,

Karadeniz Technical University Faculty of Medicine, Department of Infectious Diseases and Clinical

Microbiology, Trabzon, Turkey

E-mail: faslanaksoy@yahoo.com 0RCID ID: orcid.org/0000-0002-1926-1273

Received/Geliş Tarihi: 19.12.2018 Accepted/Kabul Tarihi: 16.07.2019

oCopyright 2019 by the Infectious Diseases and Clinical Microbiology Specialty Society of Turkey Mediterranean Journal of Infection, Microbes and Antimicrobials published by Galenos Yayınevi.
Presented in: This case is presented as poster announcement in the $6^{\text {th }}$ Turkey EKMUD Scientific Platform. 
also occasionally been referred to in the literature as non-HIV AIDS (NHA) $)^{[4,5]}$. Patients with ICL are frequently symptomatic and present with opportunistic infections, malignancies, and autoimmune diseases ${ }^{[6]}$. ICL is usually diagnosed in middle age $\mathrm{e}^{[7]}$. In patients with opportunistic infections detected in adulthood, the immune system should be evaluated for $\mathrm{ICL}^{[1]}$.

Nocardia species are opportunistic microorganisms that often cause infection in immunocompromised individual $s^{[8]}$. As the signs and symptoms of infection are mostly nonspecific, there may be delays in diagnosis and treatment. In this study, we present a patient who was diagnosed with NHA and developed an intracranial brain abscess due to Norcardia farcinica. Our aim is to highlight the fact that adult patients with recurrent or refractory infections in which opportunistic pathogens are identified, may have an underlying immunosuppressive disease, and that it may not be possible to eliminate these infections unless the underlying disease is identified and treated.

\section{Case Report}

A 50-year-old man had previously presented to another center with a 10-day history of headache and loss of strength in his right leg and right arm. His previous history in that hospital is as follows; brain magnetic resonance imaging (MRI) revealed a mass in the left frontoparietal lobe that was interpreted as metastasis. Thoracic computed tomography (CT), abdominal $M R I$, and contrast-enhanced cervical, thoracic, and lumbar MRI were performed to investigate whether it was a focal or metastatic mass. Thoracic CT revealed a suspicious lesion in the left lung consistent with malignancy. Pathological examination of a biopsy specimen obtained from the lung lesion was reported as chronic inflammatory fibrotic tissue. One week later, the patient underwent surgery (left parietal craniotomy, tumor excision, and duraplasty) for the intracranial mass. The pathology report indicated brain tissue containing neutrophils, necrosis, and clusters of cellular debris and was primarily consistent with abscess content. Three days after surgery, the patient's complaints regressed and he was discharged with ceftriaxone and metronidazole therapy. However, he presented again with the same complaints 10 days after discharge. Brain MRI revealed a 31-mm diameter area in the left parietal region that could not be defined as mass or abscess, and diffusion MRI showed multiple focal increasements in signal intensity in both cerebral hemispheres. The patient was reoperated on the next day (craniotomy, abscess excision, duraplasty). Vancomycin, meropenem, and liposomal amphotericin B therapy was initiated. No microorganisms were identified in cultures obtained in the first or second operations. The results of acid-fast bacilli (AFB) and polymerase chain reaction (PCR) tests for tuberculosis were negative. Thoracic CT scan acquired two weeks after the second operation revealed a $12-\mathrm{cm}$ malignant solid tumor involving large portions of the upper and lower lobes of the left lung, as well as a reticulonodular pattern suggestive of lymphangitic spread. Left lung lobectomy was performed and the pathology result was reported as inflammatory granulation tissue including suppurative foci (consistent with abscess). Abscess cultures were negative, as were PCR and cultures for tuberculosis. His cerebrospinal fluid (CSF) tested negative for cryptococcal and echinococcal antigens. Cytomegalovirus (CMV) PCR tests were positive in CSF (341200 copies/ml) and serum (1090 copies/ml). However, CMV was not considered as the responsible pathogen and no treatment was given. Indirect hemagglutination test for Echinococcus granulosus in the blood was negative. No mass or vegetation was observed on transesophageal echocardiography. Bone marrow aspiration biopsy was reported to be normal. AntiHIV and HIV-RNA were negative. The patient was hospitalized for 2.5 months and received antimicrobial treatment (ceftriaxone, metronidazole, vancomycin, meropenem, and liposomal amphotericin B) for approximately two months according to his statement and epicrisis report from that center. No pathological examination findings persisted during follow-up except for $4 / 5$ loss of strength in the right upper and lower extremities.

The patient presented to our clinic by his own initiative to continue treatment in our center and was hospitalized for further testing and treatment. His medical history included type 2 diabetes mellitus, tuberculosis 20 years earlier, frequent lung infections, and skin lesions on his scalp that healed and reappeared occasionally until a few years ago.

On physical examination, his general condition was good and vital signs were stable. There was $4 / 5$ loss of strength in his right arm and leg. His laboratory tests were as follows: white blood cell count $8290 / \mathrm{mm}^{3}$, platelet count $232000 / \mathrm{mm}^{3}$, hemoglobin 10 $\mathrm{g} / \mathrm{dl}$, hematocrit $28.7 \%$, erythrocyte sedimentation rate $2 \mathrm{~mm} / \mathrm{h}$, C-reactive protein $0.5 \mathrm{mg} / \mathrm{dl}$, and procalcitonin $0.17 \mu \mathrm{g} / \mathrm{L}$. Brain MRI was performed due to his persistent complaints (Figure 1).

He was treated with meropenem and linezolid for 26 days. Because the infectious focus and agent could not be identified during the course of inpatient treatment. However, several tests were planned to investigate underlying predisposing factors. Investigations for immunodeficiency were also performed. These tests revealed that the patient's CD4+ T-lymphocyte count was $263 / \mathrm{mm}^{3}$ (anti-HIV and HIV-RNA negative). Of the immunoglobulins (lg), IgG was $371 \mathrm{mg} / \mathrm{dl}(\mathrm{N}$ : 700-1600) and $\lg A, \lg M_{1}$ and $\lg E$ were normal. Kappa light chain value was 92.9 $\mathrm{mg} / \mathrm{dl}$ (170-370) and lambda light chain value was $57.5 \mathrm{mg} / \mathrm{dl}$ (90-210). Since the patient exhibited no pulmonary findings at admission to our center, no respiratory tract samples (sputum, bronchoalveolar lavage, deep tracheal aspirate) were obtained. Tuberculin skin test and interferon gamma release assay test were not performed. Furthermore, no microbiological testing was done due to the lack of gastrointestinal symptoms such 
as diarrhea. Suspecting humoral immunodeficiency and ICL, the patient was started on intravenous immunoglobulin therapy once a month. Magnetic resonance imaging was performed again on day 26 of treatment (Figure 2). Since etiological investigations yielded no causative agent, we planned to discontinue antibiotic therapy and repeat the invasive diagnostic tests. After 26 days of inpatient treatment, his antimicrobial therapy was discontinued and he was followed on an outpatient basis. At his 1-week follow-up visit, the patient did not consent to the interventional methods. Thus, further testing could not be done.

He provided consent approximately two weeks after discharge and underwent lumbar puncture. There was no growth in his CSF culture. Acid-fast bacilli and PCR tests for tuberculosis and Toxoplasma PCR were negative. Yeast was not detected in India ink screening for cryptococci. CMV PCR was negative in blood and CSF. Diagnostic biopsy of the intracranial lesion was planned, but the patient did not consent to the procedure. The patient was uncooperative regarding testing and treatment, and the inability to obtain samples delayed targeted treatment. There was uncertainty in terms of consecutive treatment (antituberculosis, antifungal, antianaerobic, antistaphylococcal) due to the lack of guiding evidence. Three weeks after discharge, the patient was admitted to the emergency department with fever, weakness in the right arm and leg, and poor general condition. Brain MRI demonstrated reduction of the bilateral abscess formations in the cerebral and cerebellar parenchyma; however, unlike the

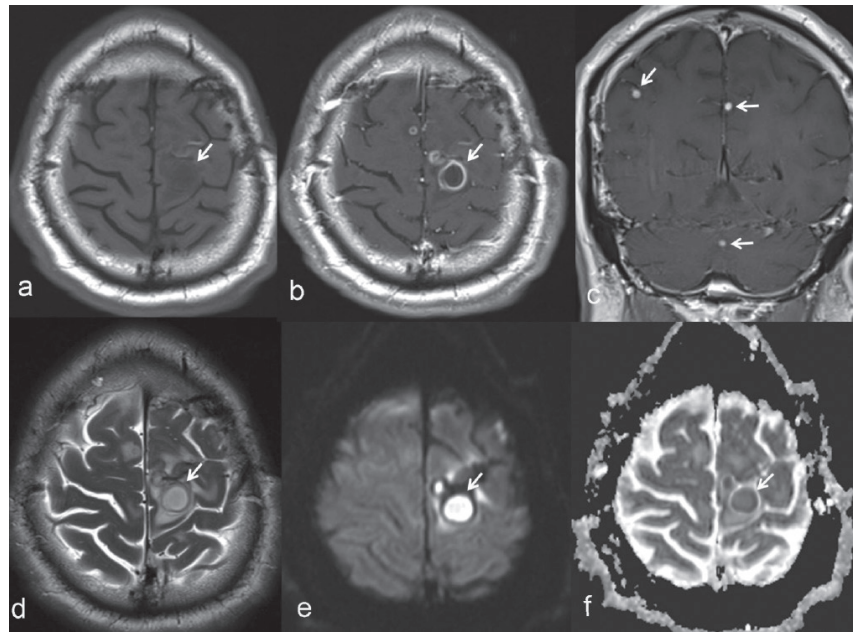

Figure 1. Brain magnetic resonance imaging (MRI) at time of admission. The lesion in the precentral gyrus of the left frontal lobe is hypointense on non-contrast T1-weighted axial MRI (a). The lesion shows annular enhancement (arrow) on contrastenhanced T1-weighted axial MRI (b). Contrast-enhanced coronal T1-weighted image reveals multiple smaller enhancing lesions in the cerebral parenchyma (c). The hypointense ring around the frontal precentral gyrus lesion on T2-weighted MRI examination (d) and its marked diffusion restriction on diffusion MRI $(e, f)$ are consistent with abscess

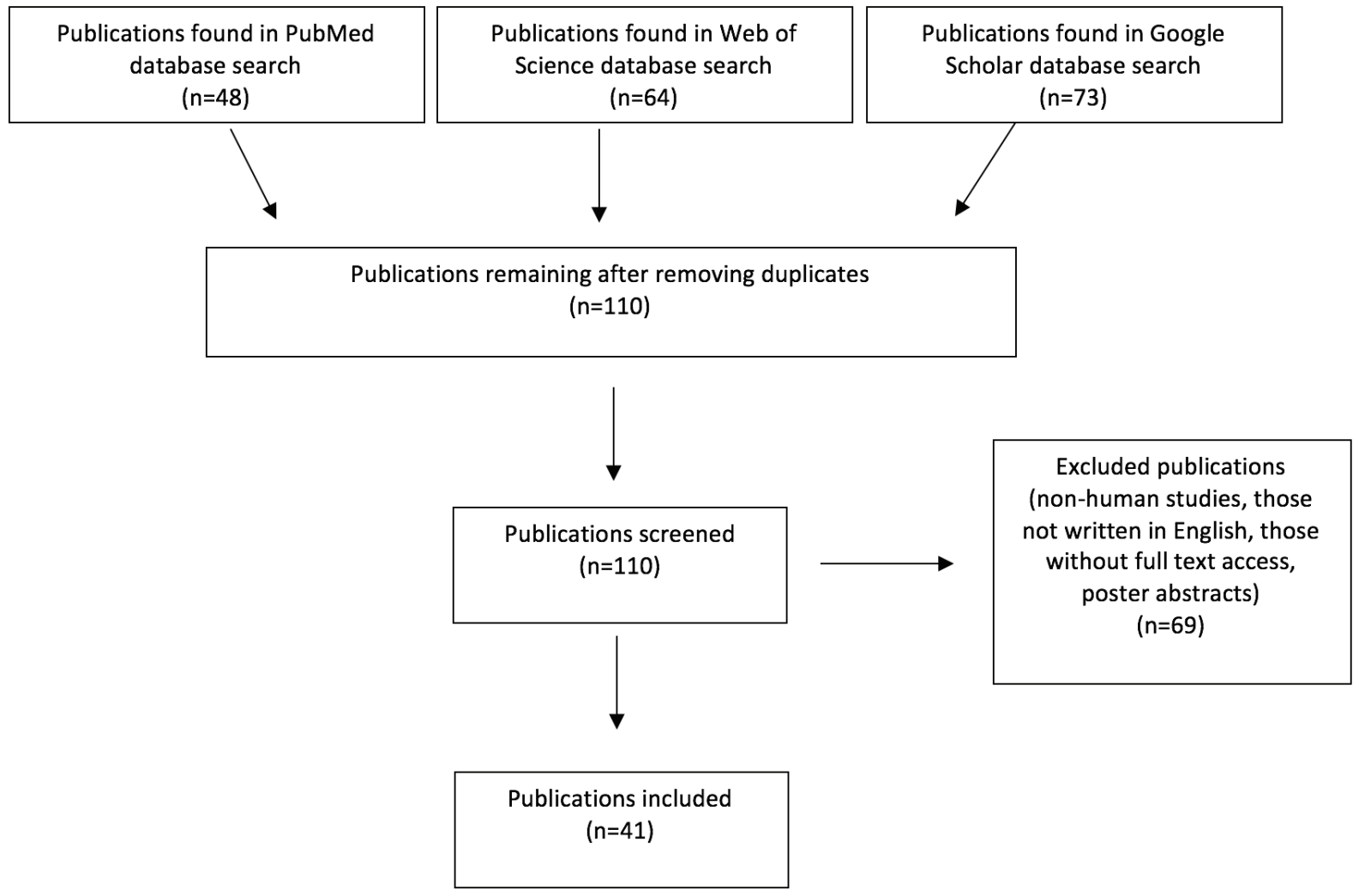

Algorithm 1. Flow chart showing the number of publications screened, evaluated for suitability, and included in the study 
previous MRI, new abscess formations up to $1.5 \mathrm{~cm}$ in diameter showing diffuse right choroid plexus involvement and intense central diffusion restriction were observed (Figure 3). Upon finding that CD4+ T-lymphocyte count was $162 / \mathrm{mm}^{3}$, the patient was hospitalized and started on empirical trimethoprim, sulfamethoxazole, meropenem, and antituberculosis therapy for his abscess. On day five of treatment, his general condition deteriorated and he was transferred to the intensive care unit where he was intubated. Two days later, he underwent craniotomy and abscess drainage. $N$. farcinica was isolated in abscess cultures. The pathogen was identified at the species level using matrix-assisted laser desorption ionization-time of flight mass spectrometry (MALDI-TOF MS) (BrukerDaltonics, Bremen, Germany). Antibiotic susceptibility testing for $N$. farcinica was not performed. Antituberculosis therapy was discontinued and linezolid was added to his treatment. The patient was monitored with mechanical ventilation and died on day 21 of antimicrobial treatment.

\section{Review of the literature}

In March 10, 2019 we searched the literature from April 2012 to December 2018 for articles about ICL and its associated infections. In 2013, Ahmad et al. ${ }^{[7]}$ reviewed all cases that occurred until April 2012, so all patients over the age of 18 reported after this date were included in our study. The keywords "idiopathic CD4 Iymphocytopenia", "idiopathic CD4+ T-lymphocytopenia", and "non-HIV AIDS" were used to search PubMed, Google Scholar, and Web of Science. The studies evaluated in the literature review are shown in Table 1 and Algorithm 1.

Of the 43 patients evaluated, 34 were male and 9 were female. Their mean age was $47.1 \pm 14.3$ years and their mean CD4 count was $133.2 \pm 86.6 / \mathrm{mm}^{3}$. Disseminated infection was observed in $16.3 \%(n=7)$ of the cases, while single organ involvement was present in $83.7 \%(n=36)$. The most commonly infected organ was the brain $(46.5 \%, n=20)$, followed by the lungs $(18.6 \%$, $\mathrm{n}=8$ ). The microorganisms most commonly isolated from these infections were Cryptococcus species (32.6\%, $n=14)$, while

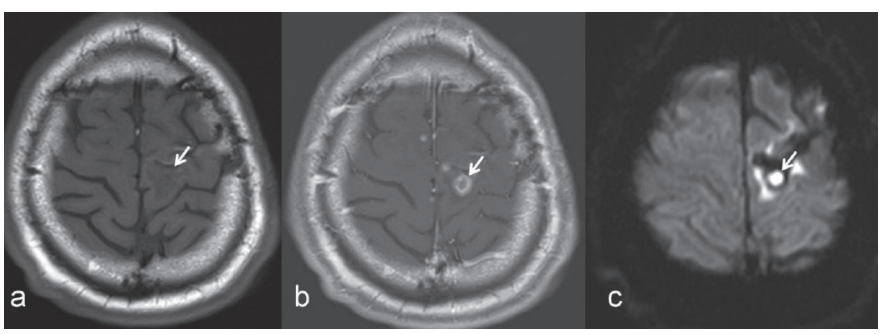

Figure 2. Brain magnetic resonance imaging (MRI) after antimicrobial therapy. After antimicrobial therapy, the lesion showing hypointensity on T1-weighted MRI (a) and annular enhancement on contrast-enhanced MRI (b) is reduced in size. Diffusion MRI (c) shows persistent diffusion restriction consistent with an abscess
Nocardia species was isolated in $4.7 \%(n=2)$. Mortality occurred in $18.6 \%(n=8)$ of the cases, with brain involvement in $50 \%$ $(n=4)$ of those patients (Table 1$)$.

\section{Discussion}

Idiopathic CD4 Iymphocytopenia is characterized by low CD4 count and opportunistic infections ${ }^{[2,17]}$. Idiopathic CD4 lymphocytopenia has also been called NHA and HIV-negative AIDS in the medical literature ${ }^{[4,5]}$. In the presented case, CD4+ T-lymphocytopenia was detected at two different times (263/ $\mathrm{mm}^{3}$ and $162 / \mathrm{mm}^{3}$ ) and HIV antibody and HIV-RNA tests were negative. Before presenting to our hospital, hemograms performed at the other center had also revealed lymphopenia. The patient was diagnosed with ICL based on these findings. Idiopathic CD4 Iymphocytopenia is very rare and is usually seen in adulthood ${ }^{[7]}$. Our patient was 50 -year-old.

Opportunistic infections are frequent in patients with ICL. In a retrospective study of $24 \mathrm{ICL}$ patients, 71\% were found to have opportunistic infections ${ }^{[50]}$. In a review of 258 ICL cases between 1989 and 2012, 87.6\% of patients had opportunistic infections and they were most commonly caused by Cryptococcus species (26.6\%). The second most common infectious agents were Mycobacterium species (17\%) while the third most common were Candida species (16.2\%). Nocardia species were only detected in two patients ${ }^{[7]}$. Our patient had presented with complaints of headache and loss of strength in his right leg and arm. Abscess culture obtained from the patient during craniotomy and abscess drainage surgery performed due to brain abscess yielded N. farcinica, an opportunistic pathogen. Nocardia infections are rare and are frequently seen in patients receiving immunosuppressive therapy, organ transplant recipients, or HIV-infected patients ${ }^{[51-53]}$. Nocardiosis is uncommon in immunocompetent individuals, accounting for only $15 \%$ of cases $^{[54]}$. People with cellular immunodeficiency are at high risk for opportunistic infections ${ }^{[55]}$. Similarly, ICL was identified as the cause of cellular immunodeficiency in our patient and he also developed intracranial nocardiosis as an opportunistic infection. One of the two cases of nocardiosis found in our

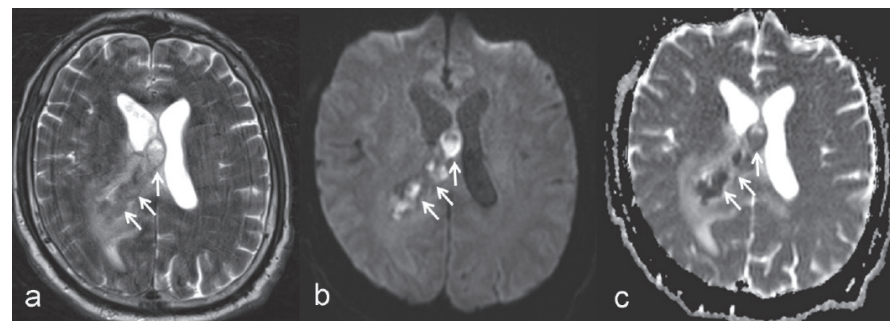

Figure 3. Final magnetic resonance imaging (MRI) images. Axial T2-weighted MRI (a) shows lesions in the right choroid plexus with lobulated contour, multicystic features, and hypointense membrane (arrows). On diffusion MRI (b, c), the marked diffusion restriction of the multicystic lesion is consistent with an abscess 
Table 1. Literature review of patients with idiopathic CD4 lymphocytopenia

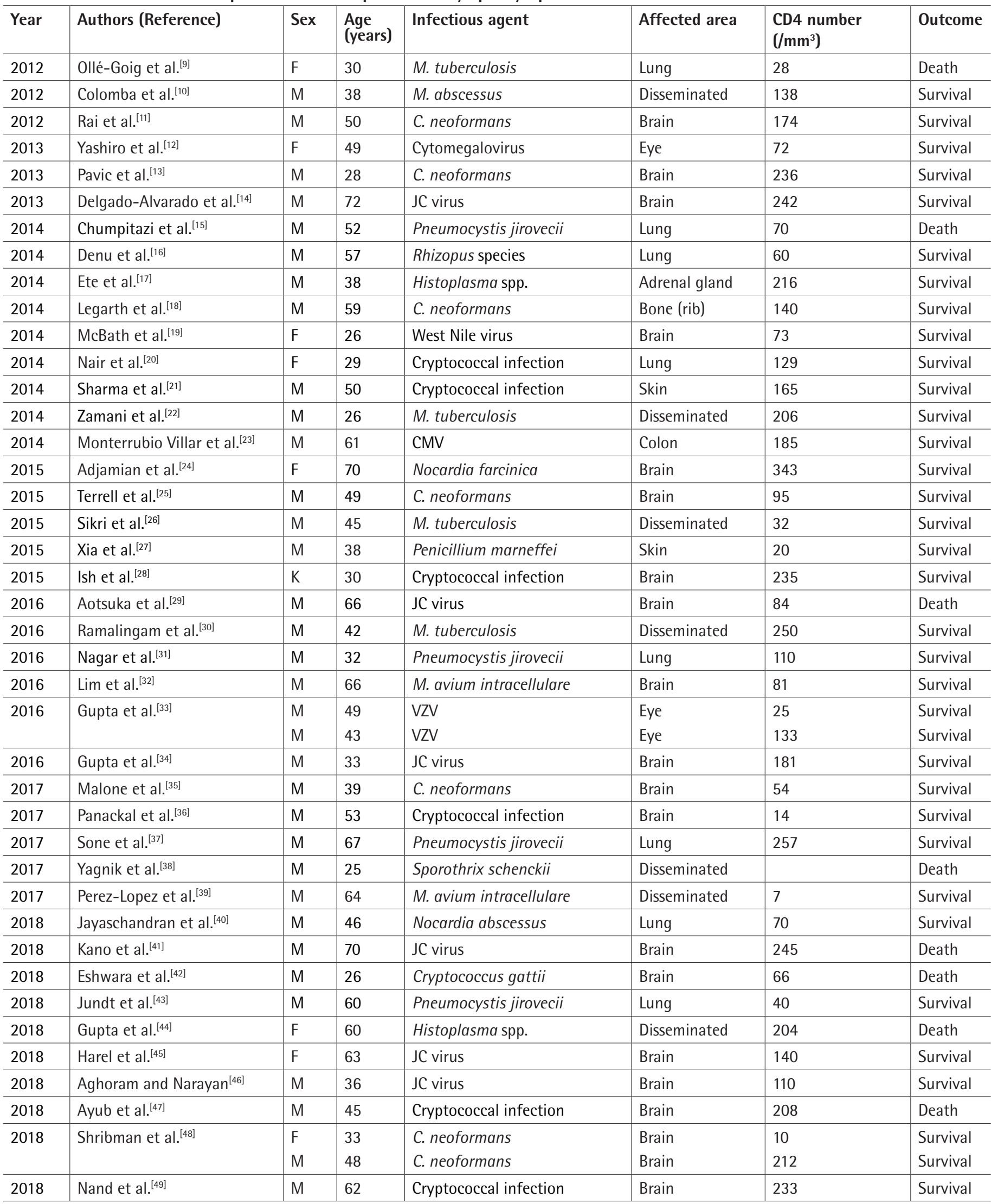

CMV: Cytomegalovirus, VZV: Varicella-zoster virus 
literature review also had brain involvement, like our patient (Table 1). Although physical examination at admission revealed no dermal involvement in our patient, ICL patients presenting with dermal symptoms and findings have been reported ${ }^{[7,56,57]}$. The skin lesions on the scalp described by our patient in his medical history might have been associated with ICL.

There is no standard treatment for ICL. The associated opportunistic infections are treated. Treatments that increase CD4+ T-lymphocyte counts such as interleukin 2 and hematopoietic stem cell transplantation may be used, but the data regarding these approaches are anecdotal and there have been no controlled studies ${ }^{[58,59]}$. Other cytokines like interferon-gamma and interleukin-7 have also been used for treatment ${ }^{[58,60]}$. Since there is no specific and valid treatment was not identified in our case, we could not address the ICL. Hence, we provided symptomatic supportive therapy and treated the opportunistic infection.

Central nervous system involvement is reported in approximately half of disseminated nocardiosis cases in the literature ${ }^{[61]}$, while our patient developed lesions in both the lung and brain (detected in the other center and during follow-up in our hospital). Although N. farcinica was isolated from the brain lesion, the lung lesion sample was only sent for histopathological examination and was not cultured; therefore, no microorganism could be identified. However, the lung lesions might also have been nocardiosis. Tumors can be clinically and/or radiologically misinterpreted as abscesses. Therefore, differential diagnosis should be made carefully and microbiological evaluation of tissue samples is imperative ${ }^{[62]}$. Before admission to our center, our patient was followed at another hospital for about 2.5 months and the pathogen responsible for his brain abscess could not be isolated there. When samples are obtained from patients for microbial culture, the microbiology laboratory should be informed about suspected diagnoses. This makes it more likely that the samples will be cultivated in special media under appropriate conditions, thus increasing the chance of isolating the agent. We do not know the culture conditions used at the other hospital. In our hospital, the agent was isolated in both aerobic culture and Nocardia culture. Antibiotic susceptibility tests could not be performed. In cases such as this, we believe that isolation of the agent is imperative to enable a more precise approach with targeted treatment.

Combination therapy is recommended for Nocardia infections ${ }^{[5]}$. Sulfonamides are the first choice, and alternative therapies include carbapenems, third-generation cephalosporins, and amikacin. The in vitro and in vivo efficacy of linezolid has also been reported ${ }^{[63]}$. Tigecycline was also shown to be effective in $v^{i t r o}{ }^{[55]}$. Moxifloxacin has been successfully used alone or in combination with other agents in the treatment of brain abscesses caused by $N$. farcinica, which is resistant to various antimicrobial agents. Treatment duration in nocardiosis varies based on system involvement; the average duration is 6-12 months and treatment is prolonged in patients with central nervous system involvement and those with immunosuppression ${ }^{[8,64,65]}$. In our case, we administered combination antimicrobial therapy with trimethoprim, sulfamethoxazole, meropenem, and linezolid. Because a causative agent could not be isolated as the etiology, we decided to follow the patient without antibiotics for a period of time before performing diagnostic procedures (he had used long-term antibiotics at the other center). He was followed on an outpatient basis but refused interventional procedures other than lumbar puncture. When the patient presented to the hospital again, his clinical presentation had worsened. We attribute this to the inadequate duration of antimicrobial therapy and the lack of treatment for his underlying ICL. Another reason for his lack of response to treatment may be the advanced infection with $N$. farcinica, which is a resistant microorganism.

Immunosuppression may occur in adults for reasons other than chemotherapeutics, immunosuppressants used for rheumatologic diseases, and hematological or solid organ malignancies. The possibility of an underlying immunosuppressive condition should be considered in adult patients with recurrent or undiagnosed infections, and these patients should be evaluated for immunodeficiency. In patients with infections due to opportunistic pathogens, we believe that diagnostic tests should be performed with clinical suspicion of ICL. Furthermore, considering that there are only a few case reports from Turkey, our study makes a significant contribution to the literature.

\section{Ethics}

Informed Consent: The study was a retrospective literature serch study and informed consent was not received.

Peer-review: Externally and internally peer-reviewed.

\section{Authorship Contributions}

Surgical and Medical Practices: A.R.G., G.Y., G.B., Concept: F.A., Design: I.E., A.S., Data Collection or Processing: M.A., Analysis or Interpretation: I.K., Literature Search: M.A., Writing: F.A., M.A.

Conflict of Interest: No conflict of interest was declared by the authors.

Financial Disclosure: The authors declared that this study received no financial support.

\section{References}

1. Walker UA, Warnatz K. Idiopathic CD4 lymphocytopenia. Curr Opin Rheumatol. 2006;18:389-95.

2. Centers for Disease Control (CDC). Unexplained CD4+ T-lymphocyte depletion in persons without evident HIV infection--United States. MMWR Morb Mortal Wkly Rep. 1992;41:541-5.

3. Spira TJ, Jones BM, Nicholson JK, Lal RB, Rowe T, Mawle AC, Lauter CB, Shulman JA, Monson RA. Idiopathic CD4+ T-lymphocytopenia--an analysis 
of five patients with unexplained opportunistic infections. N Engl J Med. 1993;328:386-92.

4. Banerjee A, Biswas M, Sarkar N. Non-HIV AIDS presenting with adrenal histoplasmosis and pulmonary tuberculosis: a mesmerising case report and discussion. International Journal of Research in Medical Sciences. 2017;3:2463-7.

5. Bird A. Non-HIV AIDS: nature and strategies for its management. J Antimicrob Chemother. 1996;37(Suppl B):171-83.

6. Gholamin M, Bazi A, Abbaszadegan MR. Idiopathic lymphocytopenia. Curr Opin Hematol. 2015;22:46-52.

7. Ahmad DS, Esmadi M, Steinmann WC. Idiopathic CD4 Lymphocytopenia: Spectrum of opportunistic infections, malignancies, and autoimmune diseases. Avicenna J Med. 2013;3:37-47.

8. Tania CS, David HM, Jonathan RI, Sharon CA. Nocardia Species. In: Bennett JE, Dolin R, Blaser MJ (ed). Mandell, Douglas, and Bennett's Principles and Practice of Infectious Diseases. 8th edition. Elsevier Health Sciences, 2016:2853-64.

9. Ollé-Goig JE, Ramirez J, Cervera C, Miró JM. Profound reduction of CD4+ lymphocytes without HIV infection: two cases from the horn of Africa. Afr Health Sci. 2012;12:331-3.

10. Colomba C, Rubino R, Di Carlo P, Mammina C, Bonura C, Siracusa L, Titone L, Saporito L. Probable disseminated Mycobacterium abscessus subspecies bolletii infection in a patient with idiopathic CD4+ T lymphocytopenia: a case report. J Med Case Rep. 2012;6:277.

11. Rai S, Marak RS, Jain S, Dhole TN. Posterior fossa midline cryptococcoma in a patient with idiopathic CD4 lymphocytopenia. Indian J Med Microbiol. 2012;30:367-70.

12. Yashiro $S$, Fujino $Y$, Tachikawa $N$, Inamochi $K$, Oka S. Long-term control of CMV retinitis in a patient with idiopathic CD4+ T lymphocytopenia. J Infect Chemother. 2013;19:316-20.

13. Pavic I, Cekinovic D, Begovac J, Maretic T, Civljak R, Troselj-Vukic B. Cryptococcus neoformans meningoencephalitis in a patient with idiopathic CD4+ T lymphocytopenia. Coll Antropol. 2013;37:619-23.

14. Delgado-Alvarado M, Sedano MJ, Gonzalez-Quintanilla V, de Lucas EM, Polo JM, Berciano J. Progressive multifocal leukoencephalopathy and idiopathic CD4 lymphocytopenia. J Neurol Sci. 2013;327:75-9.

15. Chumpitazi BFF, Flori P, Kern JB, Brenier-Pinchart MP, Larrat S, Minet $C$, Bouillet L, Maubon D, Pelloux H. Severe Pneumocystis jirovecii pneumonia in an idiopathic CD4+ lymphocytopenia patient: case report and review of the literature. JMM Case Rep. 2014;1:3434.

16. Denu RA, Rush PS, Ahrens SE, Westergaard RP. Idiopathic CD4 lymphocytopenia with giant cell arteritis and pulmonary mucormycosis. Med Mycol Case Rep. 2014;6:73-5.

17. Ete T, Mondal S, Sinha D, Beyong T, Warjri SB, Pal J, Ghosh A. Idiopathic CD4 lymphocytopenia with adrenal histoplasmosis. Int J Med Sci Public Health. 2014;3:1562-4.

18. Legarth RA, Christensen $M$, Calum H, Katzenstein TL, Helweg-Larsen J. Cryptococcal rib osteomyelitis as primary and only symptom of idiopathic CD4 penia. Med Mycol Case Rep. 2014;4:16-8.

19. McBath A, Stafford R, Antony SJ. Idiopathic CD4 lymphopenia associated with neuroinvasive West Nile disease: Case report and review of the literature. J Infect Public Health. 2014;7:170-3.

20. Nair JP, Athavale AU, Gawande S, Shah U, Baldi M, Gupt V, Gavali V. Disseminated Cryptococcosis with Caverno-Oesophageal Fistula in a Case of Idiopathic CD4+ T-Lymphocytopenia. J Assoc Physicians India. 2014;62:66-9.

21. Sharma D, Singh N, Kaushal S, Jain S. Isolated cutaneous cryptococcosis in clinically unsuspected idiopathic CD4 lymphocytopenia. J Cytol. 2014;31:230-2.
22. Zamani A, Yosunkaya S, Reisli İ. Idiopathic CD4 T-Lymphocytopenia In A Patient With Disseminated Tuberculosis. Respir Case Rep. 2014;3:41-6.

23. Monterrubio Villar J, Perez Holgado MV, Jimenez Delgado JD, Almaraz Velarde R, Veiga Gonzalez MD. Severe colitis due to cytomegalovirus in a patient with idiopathic CD4 lymphocytopenia. Gastroenterol Hepatol. 2014;37:464-6

24. Adjamian N, Kikam A, Wessell KR, Casselman J, Toller-Artis E, Olasokan O, Hostoffer RW. Nocardia Brain Abscess and CD4(+) Lymphocytopenia in a Previously Healthy Individual. Case Reports Immunol. 2015;2015:374956.

25. Terrell S, Shiber JR, Glassner S, Whisenant B. Cryptococcal Meningitis in a Patient with Idiopathic CD4 Lymphocytopenia. J Neuroinfect Dis. 2015;6:1-2.

26. Sikri $\mathrm{V}$, Kaur $\mathrm{H}$, Jain A. A rare case of idiopathic cluster of differentiation 4(+) T-cell lymphocytopenia presenting with disseminated tubercular infection. Indian J Crit Care Med. 2015;19:621-3.

27. Xia XJ, Shen $\mathrm{H}, \mathrm{Xu}$ AE. Cutaneous Penicillium marneffei infection in a patient with idiopathic CD4(+) lymphocytopenia. J Dermatol. 2015;42:812-4.

28. Ish $P$, Singh $H$, Anuradha $S$, Dewan R. Idiopathic CD4 lymphocytopenia presenting as cryptococcal meningitis. Astrocyte. 2015;2:38-9.

29. Aotsuka $Y$, Uzawa A, Nishimura K, Kojima K, Yamaguchi M, Makino T, Nakamichi K, Saijo $M$, Kuwabara S. Progressive Multifocal Leukoencephalopathy Localized in the Cerebellum and Brainstem Associated with Idiopathic CD4+ T Lymphocytopenia. Intern Med. 2016;55:1645-7.

30. Ramalingam P, Gayathri K, Santhakumar R, Manjunath B, Karuppuswamy $\mathrm{N}$, Vetriveeran B, Selvamani S, Vishnuram P, Natarajan K. Idiopathic CD4 Lymphocytopenia. J Assoc Physicians India. 2016;64:81-2.

31. Nagar VS, Kadu R, Chauhan SG, Chatterjee R, Kaushik A, Patel DV, Sood A. Clinically HIV but negative serology: Think of idiopathic $\mathrm{CD} 4(+)$ lymphocytopenia. Indian J Crit Care Med. 2016;20:371-3.

32. Lim MS, Bermingham N, O'Broin C, Khalil A, Keohane C, Lim C. Isolated Cerebellar Spindle Cell Pseudotumor Caused by Mycobacterium aviumIntracellulare Complex in a Patient without AIDS. World Neurosurg. 2016;90:703.

33. Gupta M, Jardeleza MS, Kim I, Durand ML, Kim L, Lobo AM. Varicella Zoster Virus Necrotizing Retinitis in Two Patients with Idiopathic CD4 Lymphocytopenia. Ocul Immunol Inflamm. 2016;24:544-8.

34. Gupta HV, Gokden M, Ramakrishnaiah RH, Archer RL. Progressive multifocal leukoencephalopathy mimicking glioma in a patient with idiopathic CD4 lymphocytopenia. Acta Neurol Belg. 2016;116:391-4.

35. Malone C, Gupta ND, Kothari A, Palacios E, Neitzschman H. Radiology Case of the Month: Idiopathic CD4 Lymphocytopenia. J La State Med Soc. 2017; 169:85-7.

36. Panackal AA, Rosen LB, Uzel G, Davis MJ, Hu G, Adeyemo A, Tekola-Ayele F, Lisco A, Diachok C, Kim JD, Shaw D, Sereti I, Stoddard J, Niemela J, Rosenzweig SD, Bennett JE, Williamson PR. Susceptibility to Cryptococcal Meningoencephalitis Associated With Idiopathic CD4+ Lymphopenia and Secondary Germline or Acquired Defects. Open Forum Infect Dis. 2017;4:82.

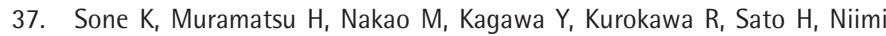
A. A Case of Pneumocystis Pneumonia Secondary to Idiopathic CD4+ T-lymphocytopenia: A Comparison of AIDS and Non-AIDS Patients. Intern Med. 2018;57:383-6.

38. Yagnik KJ, Skelton WP, Olson A, Trillo CA, Lascano J. A rare case of disseminated Sporothrix schenckii with bone marrow involvement in a patient with idiopathic CD4 lymphocytopenia. IDCases. 2017;9:70-2.

39. Perez-Lopez CJ, Arroyo E, Rodriguez M, Ortiz D, Nazario S. Disseminated Mycobacterium avium intracellulare leading to 
protein-losing enteropathy in an elderly man with idiopathic CD4 lymphocytopenia. Ann Allergy Asthma Immunol. 2017;119:390-1.

40. Jayaschandran V, Gjorgova-Gjeorgjievski S, Siddique H. Pulmonary nocardiosis in a patient with idiopathic CD4 T-lymphocytopenia. Respirol Case Rep. 2018;6:e00283.

41. Kano $Y$, Inoue $H$, Sakurai $K$, Yoshida M, Miura Y, Nakamichi K, Saijo $M$, Yuasa H. Idiopathic CD4-positive Iymphocytopenia-associated progressive multifocal leukoencephalopathy confirmed by brain biopsy following negative results of repeated CSF-JC-virus tests: a case report. Rinsho Shinkeigaku. 2018;58:750-5.

42. Eshwara VK, Garg R, Chandrashekhar GS, Shaw T, Mukhopadhyay C. Fatal Cryptococcus gattii meningitis with negative cryptococcal antigen test in a HIV-non-infected patient. Indian J Med Microbiol. 2018;36:439-40.

43. Jundt MC, Ayalew AM, Hartman TE, Roden AC, Koo CW. Idiopathic CD4 Lymphocytopenia with Fulminant Pneumocystis jirovecii Pneumonia. Am J Respir Crit Care Med. 2019;199:35-6.

44. Gupta S, Jain SK, Kumar R, Saxena R. Idiopathic CD4 lymphocytopenia presenting with progressive disseminated histoplasmosis. Med J Armed Forces India. 2018;74:280-3.

45. Harel $A$, Horng $S$, Gustafson $T$, Ramineni A, Farber RS, Fabian M. Successful treatment of progressive multifocal leukoencephalopathy with recombinant interleukin-7 and maraviroc in a patient with idiopathic CD4 lymphocytopenia. J Neurovirol. 2018;24:652-5.

46. Aghoram $R$, Narayan SK. Progressive multifocal leukoencephalopathy in idiopathic CD4+ lymphocytopenia. J Neurovirol. 2018;24:526-8.

47. Ayub MT, Jafar MS, Khalid M, Baig MA, Mba B. Suppressed without a Cause: A Case of Idiopathic Immune Deficiency. Cureus. 2018;10:e2009.

48. Shribman $S$, Noyce $A$, Gnanapavan $S$, Lambourne J, Harrison $T$, Schon F. Cryptococcal meningitis in apparently immunocompetent patients: association with idiopathic CD4+ lymphopenia. Pract Neurol. 2018;18:166-9.

49. Nand $N$, Jain $D$, SK R, Kumar P, Verma P. Idiopathic CD4 Lymphocytopenia with Cryptococcal Meningoencephalitis: A Rare Case Report. JIACM. 2018;19:149-52.

50. Yarmohammadi $\mathrm{H}$, Cunningham-Rundles $\mathrm{C}$. Idiopathic CD4 lymphocytopenia. Ann Allergy Asthma Immunol. 2017;119:374-8.

51. Ambrosioni J, Lew D, Garbino J. Nocardiosis: updated clinical review and experience at a tertiary center. Infection. 2010;38:8997.

52. Lebeaux D, Morelon E, Suarez F, Lanternier F, Scemla A, Frange $P$, Mainardi $J L$, Lecuit $M$, Lortholary 0 . Nocardiosis in transplant recipients. Eur J Clin Microbiol Infect Dis. 2014;33:689-702.
53. Anderson M, Kuźniar TJ. Pulmonary nocardiosis in a patient with chronic obstructive pulmonary disease--case report and literature review. Pneumonol Alergol Pol. 2012;80:565-9.

54. Budzik JM, Hosseini M, Mackinnon AC Jr, Taxy JB. Disseminated Nocardia farcinica: literature review and fatal outcome in an immunocompetent patient. Surg Infect (Larchmt). 2012;13:16370.

55. Wilson JW. Nocardiosis: updates and clinical overview. Mayo Clin Proc. 2012;87:403-7.

56. Cheung L, Weinstein M. Idiopathic CD4 T-Cell Lymphocytopenia: A Case Report of a Young Boy With Recalcitrant Warts. J Cutan Med Surg. 2016;20:470-3.

57. Mukherjee $A$, Lodha $R$, Kabra SK. Idiopathic CD4+ T-cell Iymphocytopenia. Indian J Pediatr. 2009;76:430-2.

58. Zonios D, Sheikh V, Sereti I. Idiopathic CD4 lymphocytopenia: a case of missing, wandering or ineffective T cells. Arthritis Res Ther. 2012;14:222.

59. Hamidieh AA, Pourpak Z, Hamdi A, Nabavi M, Ghavamzadeh A. Successful fludarabine-based hematopoietic stem cell transplantation in a pediatric patient with idiopathic CD4+ lymphocytopenia. Pediatr Transplant. 2013;17:109-11.

60. Alstadhaug KB, Croughs T, Henriksen S, Leboeuf C, Sereti I, Hirsch $\mathrm{HH}$, Rinaldo $\mathrm{CH}$. Treatment of progressive multifocal leukoencephalopathy with interleukin 7. JAMA Neurol. 2014;71:1030-5.

61. Anagnostou $T$, Arvanitis $M$, Kourkoumpetis TK, Desalermos $A$, Carneiro HA, Mylonakis E. Nocardiosis of the central nervous system: experience from a general hospital and review of 84 cases from the literature. Medicine (Baltimore). 2014;93:19-32.

62. Aydın M, Aksoy F, Gazioğlu G, Kaya S, Sarı A, Bayramoğlu G, Köksal i. A Case of Brain Abscess Due to Fusobacterium nucleatum Confused with Intracranial Tumor. Türk Mikrobiyol Cem Derg. 2015;45:18892.

63. Minero MV, Marín $\mathrm{M}$, Cercenado $\mathrm{E}$, Rabadán PM, Bouza $\mathrm{E}, \mathrm{Muñoz}$ P. Nocardiosis at the turn of the century. Medicine (Baltimore). 2009;88:250-61.

64. Fihman V, Berçot B, Mateo J, Losser MR, Raskine L, Riahi J, Loirat $P$, Pors MJ. First successful treatment of Nocardia farcinica brain abscess with moxifloxacin. J Infect. 2006;52:99-102.

65. Kandasamy J, Iqbal HJ, Cooke RP, Eldridge PR. Primary Nocardia farcinica brain abscess with secondary meningitis and ventriculitis in an immunocompetent patient, successfully treated with moxifloxacin. Acta Neurochir (Wien). 2008;150:505-6. 